\title{
International Before Commercial: Investigating the Pre-Commercial Phase of International New Ventures
}

\author{
Nicolai Lovdal', Oystein Moen²
}

\begin{abstract}
In this study we focus newly established companies within the wave and tidal energy industry. Companies in this industry have not yet reached the phase of commercial production and sales. Our study investigates presents three case companies, analyzing their development pattern and how they access resources through international activities in the pre-commercial phase. The results reveal extensive international activities, were the companies seek for and exploits resources from a variety of countries even the early phases of their development. In fact, they are willing to establish large part of their activities in foreign countries (and even move their home base) to access resources. A key implication for managers is the need of balancing international use of resources and international access to resources. From the perspective of policy makers, the case study illustrate how countries and regions compete in order to attract the attention from and activity of firms in an emerging industry. These companies relocate activity across borders depending on the support framework offered. For researchers, the study demonstrates the need of focus on the international dimension of firm activity as early as in the pre-commercial phase.
\end{abstract}

Keywords: International new ventures; entrepreneurship; pre-sale phase; emerging industries; renewable energy.

'Senior Consultant (PhD) Renewable Energy and International Entrepreneurship. Multiconsult AS PO 256, Skøyen 02 I 3 Oslo, Norway. +47 99796103. E-mail: Nicolai.lovdal@multiconsult.no

${ }^{2}$ Norwegian University of Science and Technology. Department of Industrial Economics and Technology Management. Albert Getz Vei IN749। Trondheim, Norway. +4773593505. E-mail: oeystein.moen@iot.ntnu.no 


\section{Introduction}

In emerging industries the time and resources necessary before having developed a product ready for the market may be substantial as described by Jones (200I). It seem reasonable to assume that start-ups in new industries gets access to funding, establish organizational structures and engage in some kind of supplier relationships before they have a product they can offer to the market.An important question is to what extent the pre-commercial phase include international activities or primarily is oriented towards the country were the new firm is established.

Already in 1979 Luostarinen collected data on inward operations and cooperative operations used by the firms during the internationalization process. The results from this study and further follow-up studies revealed that most of the companies had started their internationalization with inward operations, continued with outward operations, and finally strengthened the process with strategic alliances, networking and partnering with foreign firms (Luostarinen, 1979; Welch and Luostarinen, 1993; Korhonen et al. 1996). Except from a few studies (Jones, 200I; Coviello, 2006; Coviello and Cox 2007), the international involvement in pre-commercial phases has not been given much attention in research. In the review of early internationalizing firms Rialp et al (2005, pl62) call for "case studies to better understand the nature and processes of early internationalizing firms". Zahra (2005) agrees by pointing out the lack of empirical studies on the evolution of international new ventures.

Oviatt and McDougall's (1994, p49) has presented a widely used definition of international new ventures (INVs) " - a business organization that, from inception, seeks to derive significant competitive advantage from the use of resources and sale of outputs in multiple countries".

The definition above clearly states that research should include both the activities related to accessing and leveraging resources from international sources and the activities related to selling products in foreign markets. This study focuses on the first half of the definition.

When the internationalization of an INV is examined, the measures developed to monitor the phenomenon are typically made in ways that inherently demand the firms to already be established as exporting companies in order to be included in empirical studies. The fact that the internationalization process could have started long before there existed any commercial products are often neglected. As a consequence, most of the research is done with focus on firms with a ready-for-sale product and the sale of this product in international markets. This observation is very well described by Prasantham (2008, p379): "The tendency in the international entrepreneurship literature [is] to assume the existence of a suitable product offering that can be exploited in international markets from inception". This is a limitation when we know that it might take several years to develop a product that are ready for the market place. Hence, knowledge about of how firms use international opportunities to access and leverage resources in phases before they have a commercial product is vital to understanding the internationalization process.

Still, the existing research done seems to be strong on explaining the "second half" of the definition of an international new venture given by Oviatt and McDougall (1994), while the other half has not been properly investigated. In this paper we will focus on this research gap, examining international access and use of resources in phases before the Ist commercial international sale.

Based on a presentation of the development paths of three companies in the marine renewable energy industry (companies developing technologies to harness wave or tidal energy), we are able to present insight in the early phase development processes. On an evolutionary lifeline the marine renewable energy industry could be defined to be in the introduction phase (Anderson, 1984). There is no dominant design in the industry (IEA, 2006) while there are several firms worldwide in the full scale demonstration phase - i.e. just before a potential commercial break through. Most likely the marine energy industry will result in a number of new ventures with significant growth potential.

The paper is organized with a theoretical part focusing the international dimension of resource access build on resource based theory. This is followed by a methodology section, in the next part the three case studies are presented with time lines of their development. In the discussion section we comment on the international involvement of the case companies, followed with a conclusion and implication section were implications for investors, managers, public policy and further research are included.

\section{The international dimension of resource access}

In a network perspective it has been shown that loose relations gained early in a start-up's life are exploited when the firm sell their products on the international market (Sharma and Blomstermo 2003). Blomstermo et al (2004) found that former knowledge of international activities was perceived as an important asset in firms' ongoing internationalization process.

In a case study of three knowledge based software firms Coviello (2006) makes use of Kazanjian's (1988) four-stage life cycle model and assess network dynamics of INVs 
changes at various stages of evolution. Her findings indicate that relationship established already in the very first phases of a firm's life cycle may affect the internationalization process, but she does not assess how this relates to international sales or growth. In a follow-up publication Coviello and Cox (2007) twist the focus to assess the resource flow through the very same network. They find that the type of resources generated and targeted shifted through the evolution process.

Autio et al. (2000) investigate the impact of a firms' age at first international sale on the subsequent international growth. They find a strong positive relationship. Early entry leads to higher growth in international sales, higher international sales as a percentage of total sales and to higher total sale. They explain this as "learning advantages of newness". Autio et al. (2000, p9/2) states: “... the earlier a firm goes international, the less well established will be its political and relational allegiances, and the more likely it will be that important foreign allegiances will develop alongside domestic ones. Thus, when an entrepreneurial firm operated in foreign markets during its formation period, it is more likely to embrace an international identity than an older firm and less likely to view foreign operation as risky or costly". This is supported by Brush (1995), who found that the younger a firm is at the first international sale, the more positive is its attitude towards international markets later on.

The foundation for these studies is taken from organizational learning theories that claim learning to be most efficient in domains close to an existing knowledge base (Cohen and Levinthal, 1990). Based on the same theoretical foundation we can derive that activities made before the commercialization will influence future international sales and marketing activities (Sapienza et al. 2006).

Kuemmerle (2002) introduces a somewhat different model where he makes a distinction between the flow of knowledge from foreign countries and the flow to foreign countries. He names the former flow Home Based-Augmenting and Home Based-Exploiting. In his model the flow to and from the focal firm is focused on knowledge, but the model could also be used to illustrate the flow of e.g. capital and other resources. Based on former literature on foreign direct investment and six case studies Kuemmerle suggests that during the early stages of an international venture augmenting activities are more prevalent than exploiting activities.

Jones (200I) revealed that more than $50 \%$ of the firms in her study of high-technology firms had other activities than sale as the first internationalization activity. The first action in an internationalization process is often connected to value chain activities as R\&D, production and distribution. Hence, the process might include both outwards and inwards links, and are likely to reflect the firms' current core competence and its needs.

Penrose (1959) states that a new venture must acquire and assembly a set of resources on their way towards commercialization. Along with Zahra et al. (2003) we suggest that international activities might be an integrated part in the process when a firm access new resources or leverage existing ones. Furthermore, we suggest that international augmenting of the resource base may be closely intertwined with future access to international markets.

\section{The different resources}

In the resource based view, the competitive advantage of a firm is based on the resources the firm disposes. With lines back to the work in example by Penrose (1959) and Wernerfelt (1984), the resource based view of the firm is widely used and has as described by Crook et al (2008) received strong support. Resources may be classified as a) financial, b) physical, c) human and d) organizational capital (Barney, 1997). Earlier studies has indicated that political decisions on national level could affect opportunities regarding access to resources (Autio 2005) and market development (Foxon et al. 2005). Hence, we will treat political aspects as a separate point.

\section{Financial resources}

Coviello and Munro (1997) and Rennie (1993) define access to financial resources as a key challenge for INVs. Without financial resources, it would be almost impossible to e.g. develop advanced technology. It should be noted that firms following an incremental development path may gradually accumulate capital, while INVs often need considerable external resources for their rapid international expansion. The history of renewable energy technologies, and the characteristics of the value added from these technologies, has revealed access to governmental capital to be a crucial aspect of the industrial development (Steger 2005; Stern 2007).

Considering financial aspects, the marine renewable energy industry is part of the $\$ 150$ bn clean energy market (Boyle et al. 2009). The level of private investments in terms of venture capital and private equity in marine energy was about $\$ 55 \mathrm{~m}$ in 2006 (Greenwood et al. 2008). The development of wave or tidal energy concepts are capital intensive. Marine Institute of Ireland has made a Development \& Evaluation Protocol (Holmes et al. 2007) for wave energy concepts which include a rough budget. The estimated cost from concept verification to full scale demonstration project is $€ 9 \mathrm{~m}-€ 2 \mathrm{Im}$. 
Some countries have introduced special financial measures to support testing, demonstration and market development. Presently the UK can be considered as leading regarding financial support from the government. One example is the establishment of the Marine Renewables Deployment Fund, comprising $f 50 \mathrm{~m}$ and expected to bridge the gap between prototype tests and commercial deployment with support to initial investments and favorable tariffs on produced electricity as part of this scheme (IEA, 2006). The stated objective of the UK, i.e. in particular Scotland, is to create the world's leading marine energy industry by 2020 (MEG, 2004). Portugal has established "pilot zone" on $320 \mathrm{~km} 2$ dedicated for wave energy projects. At the same time Portugal has introduced Europe's highest feed-in tariff (fixed price) on electricity (up to $0.26 € / \mathrm{kWh}$ ) from wave energy demonstration projects (MEl, 2007). Based on the combination of need for financial resources among these firms and the differences in funding opportunities between countries an important question is: to what extent does this situation impact the international activities of the firms in the pre-commercial phase?

\section{Physical resources}

Empirical studies have identified that the key sources for competitive advantages for INVs are unique products, often related to the use of advanced technology (Moen, 1999). This indicates that the most important utilization of resources in the pre-commercial phase will be related to product/technology development. As described by Van de Vrande and Vanhaverbeke (20I2), access to test facilities may be important for small firms. Within INV research, the access to physical resources as test facilities, medium sized pilot projects or full scale demonstrations has not been focused. Considering emerging industries with high levels of technological complexity, the geographical distribution of test facilities may be important for firm level decisions and strategies.

The physical environment offered in the renewable energy industry varies considerable between countries. Development of technology to marine energy requires testing in lab and at sea. A major part of the expenses related to testing and demonstration is connected to the needed infrastructure to accomplish the tests. In full scale testing or in a commercial power park a grid connection is crucial. Hence, the existence of grid near the coast line is of high importance. There are a number of countries who have lab facilities to test scaled models in labs. However, infrastructure required to do full scale demonstrations in the sea is in particular expensive and only a few countries worldwide have invested in infrastructure to support full scale deployment. UK, with the creation of NaREC (New and Renewable Energy Centre), EMEC (European Marine Energy Centre) and the WaveHub, is the only country with a full range of test infrastructure to offer - from idea to full size parks with arrays of devices. $\mathrm{NaREC}$ is a public funded $t 30 \mathrm{~m}$ facility to develop and test renewable energy technology on prototype level. EMEC is a public funded $5 M \notin$ sea test site fully equipped for full size marine energy devices, subsidized by the EU and the Scottish Executive. WaveHub is a public funded $t 28 \mathrm{~m}$ power cable with capacity to hook up four full size wave energy parks. As a consequence, the access to physical testing and development facilities may be a significant driver for international activities in the pre-commercial phase of the firms in this industry.

\section{Human resources}

Examining existing INV research, access to human resources has not been studied in particular. The experience and background of the project founder and the composition of entrepreneurial team have been included on some studies, but not how the firm act in order to get access to the individuals and the competences they define as critical.

The first real attempts to harness wave and tidal energy in an industrial scale were triggered by the oil crisis in 1973 (Ross 1995). However, these initiatives did not manage to develop competitive technology fast enough to be price competitive when the oil price felt again and faded out. Only a few academic communities continued to do research on marine energy during the 80 -ies and early 90 -ies. Hence, there were relative few persons with expertise knowledge in the field when the activity new start-ups entered the scene late in the 90-ies and up until today. This fact made the research institutions that had continued effort within marine energy attractive as partners for technology developers worldwide. Countries like Norway, UK, Japan, Portugal and Ireland should be mentioned as examples. The industry is still influenced by the former research culture and industrial international networks have been born out of this. The EU funded research programs like WaveTrain is a good example. The WaveTrain program educates people on $\mathrm{PhD}$ level on issues relevant for wave energy, while building an international network at the same time.

Basically, it should be expected that countries with a strong maritime industry will give the best opportunity for recruitment.

\section{Organizational factors}

Organizational issues have been a core focus in INV research. Alternative governance structure was one of four elements defining an INV in Oviatt and McDougall's shaping paper on the phenomenon (1994). INVs are known to rely on less resource demanding structures than larger firms (Gabrielsson and Kirpalani, 2004). 
The marine energy industry is dominated by start-ups. In an assessment of characteristics that facilitated early internationalization in the three industries deep sea wind, wave and tidal energy Løvdal and Aspelund (20I0) reveal that $94 \%$ of all technology developers are some kind of start-ups. They also show that many of these start-ups rely on partnership as a strategy for growth and internationalization. It should be expected that the case companies have external relation to a variety of partners, but the degree of international partnerships need to be investigated.

\section{The political environment}

Løvdal and Aspelund (2010) concluded that long term governmental support, license challenges and lack of public awareness are perceived as major industry barriers within the marine energy industry. These barriers are heavily affected by national political decision, laws and regulations.

The role of institutions and political framework in building and sustaining INV's competitive advantage have been overlooked in the INV research (Zahra and George, 2002; Etemad 2004; Autio, 2005; Rialp et al. 2005; Zahra, 2005). McDougall (1989) compared INV with domestic firms and found that INV perceived governmental policies more restrictive than firms with domestic focus. It is unclear whether this was because INV seek more attractive policy context, or if it indicates that INV is confronted with increased regulatory requirements when competing abroad. However, political context and governmental institutions are well known to affect innovation and are e.g. central within innovation systems theory (for an example on renewable energy see Foxon et al. 2005; for a more general framework Bergek et al. 2008).

\section{Key points for the case studies}

We started with presenting a research gap with regard to the level and type of international activity in the pre-commercial phase of new firms. Following the arguments presented by Autio (2000), Brush (1995) and Moen (2002), it could be expected that high international involvement in the early development phases are positive for international market success when entering the sales and commercialization phase. For the specific resources we have identified key questions:

Financial resources: Public financial support schemes vary between countries, were the UK and Portugal offer the highest level of support. To what extent does this have consequences for firms established in other countries?

- $\quad$ Physical resources: Only the UK offer a full range of testing facilities, does this influence firm level decisions and strategies?
- Human resources: Countries with a strong maritime industry has better supply of competent employees, but we have limited knowledge of recruitment opportunities across national borders.

- Organizational resources: The industry is dominated by start-ups, to what extent do these firms involve in alliances with others firms? Do they develop alliances across national borders or mainly within the country they are founded in?

When considering the political environment, we have outlined how different nations have developed financial support schemes or demo/test and pilot facilities. Nations are typically motivated to facilitate the development of renewable energy technology and markets by three reasons; I) to fulfill their international climate obligations, 2) to secure the supply of energy and 3) to sustain economic growth. In total, the political environment might influence access to both financial and physical resources, and it seem likely to expect that this will be reflected in the choice of countries given attention by the case companies.

We expect to identify an effect of these resource related factors on the international involvement of the firms. But we have limited knowledge of the strength of such effects - are they key drivers of all decisions and strategies of the firms or only minor factors with limited impact? Are the choices made in the pre-commercial phase changing the entire development paths of the companies and in case what are the consequences for managers, investors, public policy and for further research?

\section{Methodology}

From a methodology perspective, our research may be described as case study with multiple case data and multiple unit of analysis (Yin, 2003). The case is the emerging marine energy industry and in-depth studies of three case companies. Case studies has been recommended to investigate complex and context-specific internationalization processes (Coviello, 1997).

The three case companies were selected based on defined criteria. They have all reached the phase "testing in real sea condition". This means they have achieved a level of maturity that indicated capabilities to develop a product and to get access to the required funding to test in large scale at sea. Further, they have all conducted extensive international activities as part of their business/technology development. Jones and Coviello (2005, p294) recommend mapping of international activities on a time line to get the grip of each firm's "fingerprint pattern and profile of internationalization behavior". To fit their framework to our case we have extended their definition of an internationalization event to 
"every international activity with the purpose of accessing, using or leveraging resources". Following the work of Sarasvathy (200I) we have not distinguish between events that have been planned (effectuation) or has occurred as a contingency (causation). Case data was gathered from public available information (web pages, conference papers, newspapers, magazines, annual reports etc). We searched for information using a variety of keywords both in open databases using Google and Google Scholar but also in ISI Web of Science, ProQuest/ABI Inform and SCOPUS. The results of these sources of literature was combined with information obtained from industrial seminars and conferences. A case description, with a set of events on a timeline, was produced on each case. Actual company names have been used on the most important events to ensure a high reliability. This description was then sent to and reviewed by a represent from the manager or founding team in each company.

To enhance external validity we have included relevant information about the political and industrial context. It was regarded as important to get access to firms within the renewable energy industry, and important to be able to present case studies were actual developments are described. By focusing on one industry we reduce the risk of getting confound results (Rouse, 1999). Still, with the use of three different cases, each with different characteristics, we are able to give a more nuanced picture of how the companies in the industry act.

\section{Case descriptions}

In the three case illustrations below we first present a timeline showing the most important internationalization events with comments. This is followed with a paragraph with as- sessments of the internationalization fingerprint related to resources and markets.

\section{AWS Ocean Energy}

Origination form the Netherlands,AWS Ocean Technology has used parts from suppliers from different countries and assembled them in Portugal.The hull came from Romania, generator parts came from France and China, a converter from Germany, the submarine cable came from Italy and some parts came from the Netherlands. The deployment of the device was a trial and error process with several local suppliers involved.

When succeeding in deployment of the full scale device they became the most powerful grid-connected offshore wave energy generator in the world. After gaining experience in Portugal a company was set up in Scotland to commercialize the technology. Shortly after, the majority shares of the Scotland based company was bought by a London based investment firm. The new board included senior personnel with experience from Gamesa, Spain's leading wind turbine producer, and management of private equity investments in international energy projects. The new management team aims to make a new test of the device at European Marine Energy Centre (EMEC) in Scotland. To be able to deploy a new test device they received new public funding directly from the Scotland Executive. Further, they got funding from the UK based public agency Carbon Trust through their initiative Marine Energy Accelerator whose aim is to accelerate the development of promising low-carbon technologies. After these initiatives they first secured investment from the Dutch oil \& gas company Shell and an investment fund based on the Cayman Islands. Shortly after they raised new funds from Shell and from the public fund Scotland Executive.

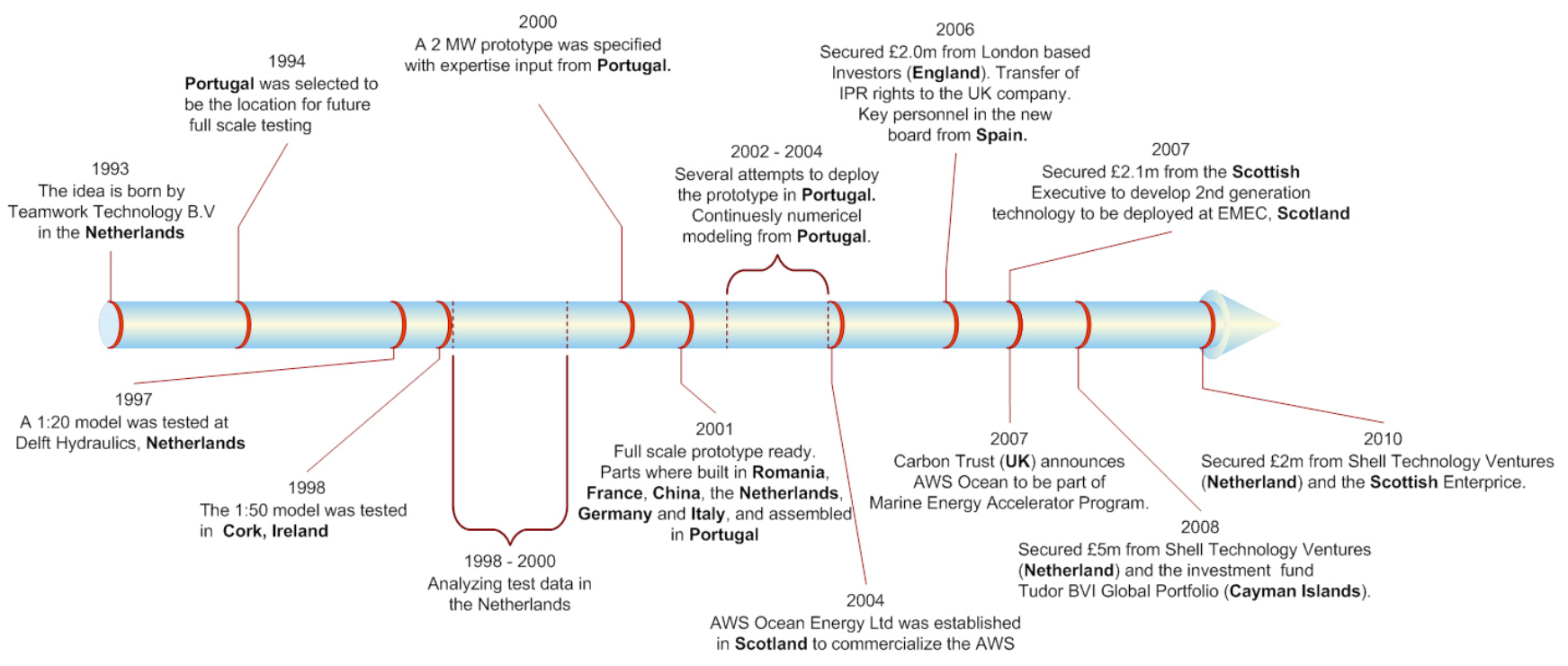

Figure I Timeline of AWS Ocean Energy

ISSN: 07 I8-2724. (http://www.jotmi.org)

Journal of Technology Management \& Innovation (c) Universidad Alberto Hurtado, Facultad de Economía y Negocios. 


\section{Internationalization fingerprint}

In the Netherlands the potential for wave energy is considered to be low and there are no tailor made political support for marine energy. However, the country has high skills and capabilities related to other marine industries such as shipping, oil \& gas and engineering. Already one year after the establishment of AWS Portugal was selected as the place to deploy their prototype. This was done to access Portugal's attractive feed-in tariff and to exploit the apparent hassle free procedure of getting a permit to deploy the device. The prototype was specified with the contribution of knowledge from Portugal. In Portugal they had earned a reputation as leading regarding hydrodynamic calculations and a semi-commercial research centre connected to the technical university was set up to provide services to the emerging wave energy industry. This centre holds a wide industrial network with value for start-ups. Before the prototype was built a scaled test of the device was done in Ireland, where they have suitable test facilities along with the needed experience.

The full size prototype was assembled in Romania because of their international competitive shipyard.After a fairly successful deployment of the prototype the company needed substantial new funding to further develop the business. A subsidiary in Scotland was set up because they knew the investment climate in Scotland was better than in the Netherlands. They found local investors in the UK and established a new independent firm and moved the full IPR over to this firm. Through this firm they have managed to get substantial governmental funding from Scotland to develop a 2 nd gen- eration device to be tested at Scotland's public funded test facilities at EMEC. Further, they managed, after a competition, to be part of a UK program where the company got financial support earmarked to accelerate the technical development. Finally, the company secured a major investment from an investment fund based on Cayman Islands together with Shell (who have their HQ in the Netherlands). This investment was topped by a public co-financed investment.

Overall, the strong international involvement has characterized the entire development process of AWS Ocean Energy.

\section{Advanced Wave Energy (AW-Energy)}

Origination from Finland, the prototype was tested in two different places in the world. First in Pacific Ocean (Ecuador), later the same year the prototype was launched at European Marine Energy Centre in Scotland to test the concept in rough Atlantic Ocean environments. After these tests were conducted AW-Energy was awarded a grant from TEKES (Finnish Funding Agency for Technology and Innovation), the main government financing and expert organization for research and technological development in Finland. The subsequent year AW-Energy secures an investment from a Finnish venture capital firm (Aura Capital) and from Sitra, the Finnish Innovation Fund. The same year the first device of a planned array was constructed and deployed in cooperation with a Portuguese construction company. They increased the activity in Portugal through a joint venture with Eneolica, a subsidiary of one of Portugal's leading business groups (Lena Group), to establish a wave energy park. Three months later Finland's biggest energy company invests

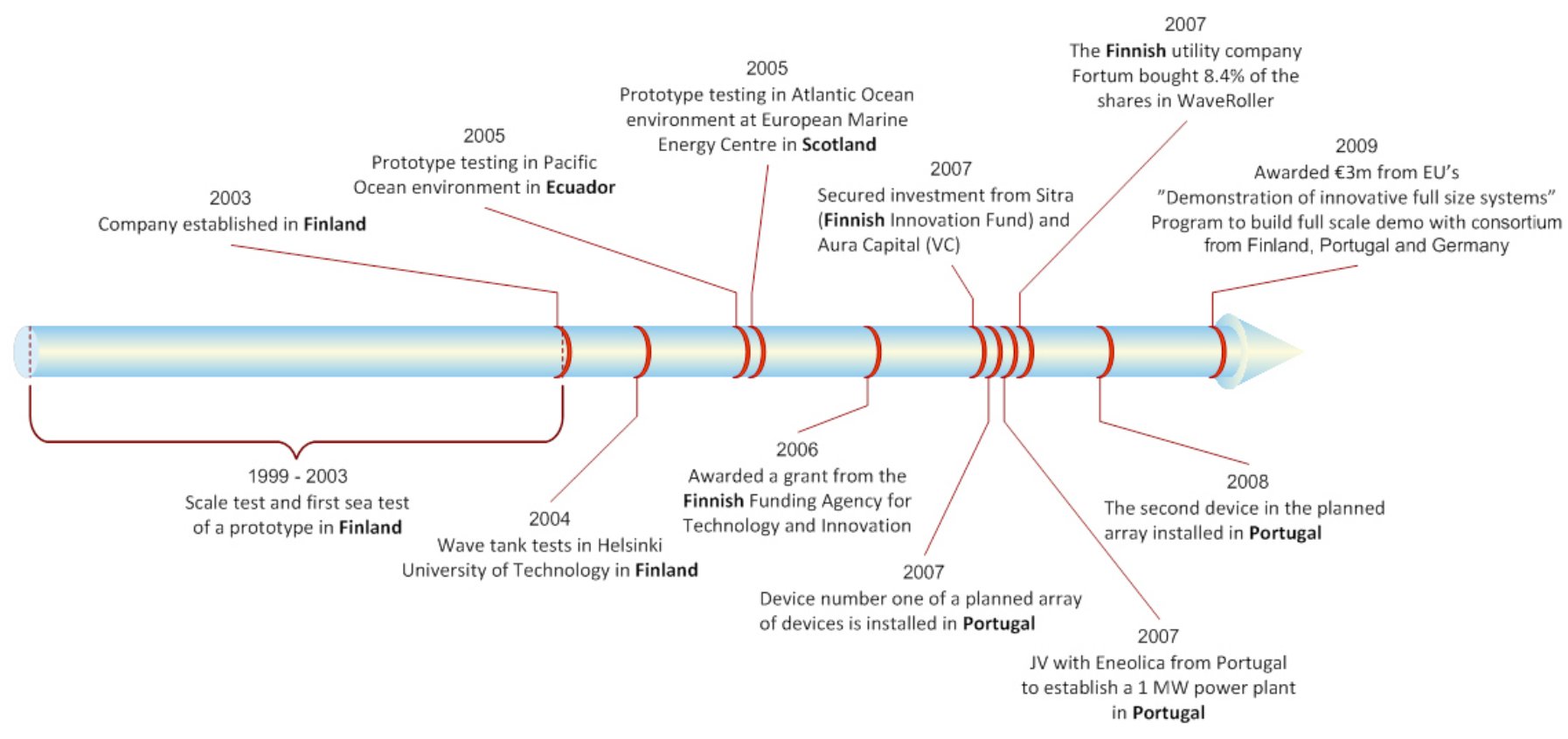

Figure 2 Timeline of Advanced Wave Energy

ISSN: 07I 8-2724. (http://www.jotmi.org)

Journal of Technology Management \& Innovation (c) Universidad Alberto Hurtado, Facultad de Economía y Negocios. 
an undisclosed sum in AW-Energy to get $8.4 \%$ of the shares. The recent development is the awarding of $€ 3 \mathrm{~m}$ from EU's new funding program for ocean energy "Demonstration of innovative full size systems".

\section{Internationalization fingerprint}

The potential of wave energy in Finland must be regarded as low and there are no particular political measures to develop marine energy. As a consequence, AW-Energy had to aim for the international market. By performing tests in both the Pacific and the Atlantic Ocean they gained experience from different environments in the world and were in a better position to judge the appropriateness of their technology at different climate and wave conditions. Just as we saw in the case of AWS, AW-Energy has explored the option of using existing infrastructure for testing at EMEC, Scotland. After conducting test abroad the company secured financial capital in form of grants and investments from Finnish state owned funds. With international experience from testing and with new funding they establish a project in Portugal with local partners through contracts and the joint venture establishment.As with the case of AWS, this was done to exploit the attractive electricity price given for electricity from wave energy in Portugal.Again, we can observe that a big player from the country where the idea was born invests in the start-up after they have built an initial basis of resources and international experience. Finally, we can see that the combination of AW-Energy's partners and their own resource base put them in a position where they are granted significant funding from EU to build a full scale project.

\section{Ocean Power Technologies (OPT)}

Ocean Power Technology was incorporated already in 1984 in the US, but the first commercial activity and the development of their wave energy technology was first initiated from 1994. Shortly after OPT announced an agreement with the Japanese construction company Penta-Ocean to develop a prototype of a wave energy device. The Japanese company part funded the development. In return, OPT gave PentaOcean exclusive rights to market its product in Japan. During the rest of the 90-ies OPT developed their technology and did research for the US Navy to study the feasibility of wave energy. US Navy has since then been an important income source for OPT. The US navy has bought research services for more than $\$ 18 \mathrm{~m}$ (Fedspending 2009) and has funded many tests allowing OPT to develop their technology. Early in this century OPT established a subsidiary in Australia and sold $5 \%$ of the mother company to the Australian energy company Woodside. In 2003 OPT was listed on London's Alternative Invest Market stock exchange and raised $£ 22.4 \mathrm{~m}$ on the initial offering. The following year they established a subsidiary in UK who soon formed a joint venture with the Spanish utility company lberdrola and made an agreement with the energy company Total of France to investigate the potential to develop wave energy projects in France. The UK subsidiary was awarded (as one of four companies after competition) a position at the $£ 28 \mathrm{~m}$ public funded WaveHub in England. The same year the mother company applied for permits to develop a wave farm in the US and signed a marketing cooperation with Lockheed Martin, making them

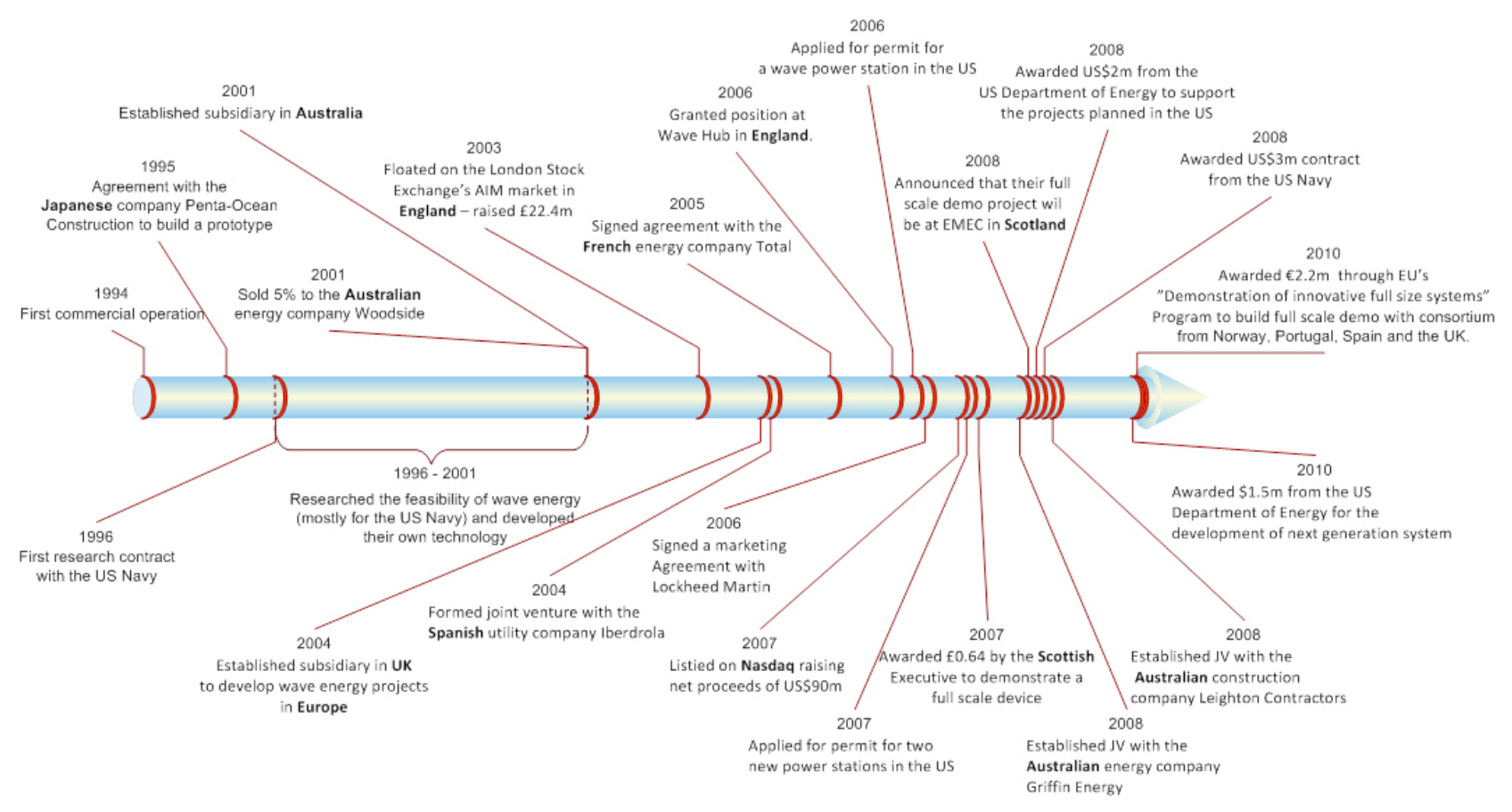

Figure 3 Timeline of Ocean Power Technologies

ISSN: 07 I8-2724. (http://www.jotmi.org)

Journal of Technology Management \& Innovation (c) Universidad Alberto Hurtado, Facultad de Economía y Negocios. 
a global partner. In 2007 OPT was awarded a grant from the Scottish Executive to build a full scale demonstration device. This demo project will be placed at EMEC in Scotland. Further, the same year, OPT applied for permit to develop two new wave farms in US. 2007 was concluded with OPT taking the company to NASDAQ raising new $\$ 90 \mathrm{~m}$. In 2008 OPT announced two new JV to develop wave energy projects, this time in Australia. Further, they were awarded $\$ 2.0 \mathrm{~m}$ from the Department of Energy to support a wave energy project in US and received a new $\$ 3.0 \mathrm{~m}$ contract with the US navy.

\section{Internationalization fingerprint}

The OPT case is an extreme example of how a company can have extensive international activities without really having entered the stage where they have a fully commercial product to offer.Very early the company made an agreement with a Japanese company where they exchanged technology and funding with an exclusive right to market the product in Japan. Through this move they leveraged their resources and got a future option for foreign sale. OPT have established several joint ventures and agreements with leading foreign companies to prepare future sales in foreign countries, either through their mother company or through one of the subsidiary. They have also established a marketing agreement with a global player who they have been cooperated with in their home market on research project related to the core technology. The following statement is from the annual report (OceanPowerTechnologies 2008, p 9):"By collaborating with leaders in renewable energy development, we believe we are able to accelerate both our in-house knowledge of the utility power generation market and our reputation as a credible renewable energy equipment supplier". As we noticed on the two former case, OPT do also plan to exploit existing infrastructure in Scotland and England to build their first full scale demonstration and a full scale power park.

OPT was the first company who is listed in US after being listed at the London Stock Exchange's AIM market and is by far the company within marine energy who have raised the most money. We see they have exploited the favorable context of the London Stock Exchange and political framework in the UK to achieve substantial funding from both private and governmental sources. After building an extensive portfolio of international and national projects OPT float on the NASDAQ stock exchange to get access to more funding.

\section{Discussion}

Both Rialp et al (2005) and Zahra (2005) stated a need for studies on the evolution of international new ventures in order to increase our understanding of their development paths in the early phases. In the final section of the theoreti- cal part we asked if the international, resource oriented factors would be key drivers of all decisions and strategies of the firms or only minor factors with limited impact? Based on the three cases, the answer is straightforward: These firms are highly international prior to the commercialization phase, and the international, resource access processes fundamentally drives the development of the companies. We would like to point to some specific observations based on these case companies:

First, the access testing and development infrastructure has resulted in strong orientation towards Scotland and Portugal in particular. The resources they offer are typically infrastructure for testing, concession regulations, financial support schemes and other resources related to national policy. Hence, early internationalization decisions seem to be highly affected by national political context in different markets. We also found that start-ups are willing to establish activities in foreign countries to access the necessary resources.

Second, we found that start-ups establish projects related to technology development and funding (use of strategic alliances and partnerships) with a broader geographical scope. In this search for partners, the variation with regard to which countries they include seem to vary to a much higher extent than for testing and development.

Third, we also observe heterogeneity between different nations' ability to provide testing and development infrastructure. On a national level, the development of a marine energy industry may be regarded as a valuable resource and the policy makers seek to provide resources that firms in that particular industry find valuable on their level.A important characteristics of the testing and development infrastructure is that they are immobile (Peteraf, 1997) in the sense that they cannot be accessed without doing physical activities inside the nation where they are provided. Still, foreign companies can aim to access them - if they are willing to relocate some activities. Following Collis and Montgomery, competitive advantages can be attributed "to the ownership of valuable resources that enables the company to perform its activities better or more cheaply than the competitors" (1999, p.27). In an earlier publication (Collis and Montgomery, 1997, p.30) the same authors defined the value of a firm's resources to lie "in the complex interplay between the firm and its competitive environment along the dimensions of demand, scarcity, and appropriation". By reflecting these statements on our findings from the marine energy industry we suggest that the existence and importance of the immobile resources can be understood by combining the lenses of the nation offering the resources and the firms accessing them. Some nations are in more need than others to facilitate certain industries (Encamation and Wells Jr., 1986). 
Fourth, when examining the different types of resources, human resources do not seem to be important in relation to the international dimension. Basically, this is not regarded as a critical factor for any of the companies. It seem as they expect recruitment to be more a function of their financial strength than depending on where they locate activity. Also, human resources may be regarded as easier to transfer (move) between geographical locations than in example testing infrastructure.

Fifth, instead of headquarters Kuemmerle (2002, p I04) expanded on Porter (1990) and introduced the expression "home base" defined as "the location where strategic decisions are made, where resources are allocated, and where knowledge is managed" where "all ventures start from or converge to one home base". The interesting question with major impact is whether companies are willing to change the location of their home base. AWS have not only inward and outward activities (Jones, 200I), but have moved their headquarters to another country to change the political context which they were operating in to get better access to the immobile resources described above. As a Scottish company they have received substantial governmental support from Scotland and the UK.The same principle applies to OPT, who established a subsidiary in UK, and then received substantial governmental support in UK and was listed on London's AIM stock exchange. We quote OPT's CEO (Taylor 2006, p.66): "Traditionally when companies listed they tended to do so in the countries where they were headquartered. But for an increasing number of renewable energy companies it makes perfect sense to look further afield where the political and investor audiences are potentially more receptive, while maintaining a broad international scope". To a certain extent it would be correct to claim that even Advance Wave Energy who still holds their headquarters in Finland have changed the context they are operating in. After they had done the initial test of the concept their main activities have been abroad and their first full scale test is done in Portugal where the governmental support is attractive.

The international entrepreneurship literature have studied the phenomenon of hybrid structures (Gabrielsson and Kirpalani, 2004), but in these cases we observe a whole industry that are willing to place their core activities in foreign countries to access valuable resources in a pre-commercial phase. Some of they are even willing to move their strategic home base.

Sixt, from former research we have seen that companies established in proximity to an industry hot spot (Pouder and Caron, 1996) receive more investments from international investors (Coombs and Deeds, 2000). In addition, we see from the OPT case that they use their unfinished technology to secure future access to key markets all over the world.
A statement taken from OPT's annual report reveals this as part of a planned internationalization strategy (OceanPowerTechnologies 2008, pI0); "By enabling customers to experience our technology first-hand, we believe we will be able to facilitate our entry into our target markets". An even more extreme example is OPT's move to London's AIM stock market (LondonStockExchange 2004) that was caused by their wish to "raise our profile within Europe to help us move into this important market". The same phenomenon applies to Advanced Wave Energy, though in a smaller scale. They used the demonstration project in Portugal as an opportunity to plan the roll-out of a future power park in Portugal together with a local partner. This is part of their internationalization strategy; testing the model of alliances to prepare for a global roll-out with limited resources.

What we have seen through the case companies and the survey data is that start-ups seek to establish technology related activities in those countries that also represent future markets. We can also observe that firms make Memorandum of Agreement with large companies (typically energy companies) to part finance pilot and demo projects in the home countries of the large companies. The agreements typically include an option for the large company to further establish full scale power projects when the technology has been tested.

This observation may represent a major difference between internationalization in industries with short lead time for new innovations and in those with long lead times. In industries with long lead time we can expect the innovation to be in the overlapping phase between pre-commercial and commercial for a much longer time than in those industries with short lead time.

Finally, the pre-commercial phase may be regarded as a marked for future options. Seen from the perspective of the start-up, the activities in this phase may be regarded as part resource access and partly a preparation for sale. It is likely that activities with these characteristics are more frequent in emerging industries because large companies often seek to secure access to a portfolio of future options. Start-ups with innovative technology may be regarded as providers of new technology options that eventually may take a large market shares.

\section{Implications}

For managers, a major implication of our study is that getting access to resources internationally could be perceived as a valuable asset and could be leveraged into e.g. funding from investors. Start-ups with proven ability to maneuver in the international arena in pre-commercial phases appear as viable companies with international growth potential. 
Since no company in the whole industry can be claimed to have reached a commercial phase we cannot prove the link between international activities before commercialization with future access to international markets. However, based on the statement from our case companies we can conclude that it is an intention to exploit the international work done in early phases when they reach the commercialization phase. In addition, the location of activities in areas defined as industry "hot spots" may give access to testing infrastructure, new partners and be positive in discussion with investors. Overall, the international activities in the pre-commercial phase are important and should be carefully developed in order to position the firm for long term commercial success.

Investors should assess to which extent potential investment cases have accessed and leveraged resources internationally, and what kind of relations they have made through these activities. Early international activities may affect the international market potential. Technology development partnerships, willingness to relocate activity and use of positive support mechanism across national borders may characterize firms which develop capabilities positive for long term success potential.

For public policy, the study reveals that it is possible to attract promising foreign companies in new industries even in early phases of a company's life. The most distinct effect is as expected were some geographical areas offer immobile resources as testing and development infrastructure. Policy makers in countries where start-ups consider leaving because of better governmental support in other countries need to evaluate the risk for loosing promising start-ups before they actually start to generate income. An important observation is that the political context might be so important for start-up companies that they are willing to move the main office to a foreign country to actually change the political context. An interesting issue with high economic impact is to what extent start-ups might exploit other nation's immobile resources in the phases before Ist sale, without moving their strategic home base.

Considering implications for research, former studies has presented constructs for measuring degree of international suitable for firms who have a ready-for-sale product. Future research should develop new constructs to measure the degree of international in phases before Ist international sale. This is especially important based on the need for research focusing whether start-ups with a high international focus in early phases have a higher potential for survival and international growth. Another promising research area would be to investigate innovation speed to evaluate whether early international activities affect the speed of product development. Of particular interest is research on the phase where the start-up has a product that is unfinished, but mature enough to be of interest for potential future customer immediately before a potential commercial break through. Results from this study shows that this is the phase where managers decide which market to focus their effort.

The use of only three cases is a limitation of the study, further studies should both attempt to use a single case approach to get deeper knowledge about the development processes and use multiple case studies and surveys to build knowledge about similarities and differences between companies. In addition, other emerging industries should be included in further studies. Even with these limitations, we have been able to map the development process for each of these firms, presenting the type of extent of the early international activities of the firms.

\section{Concluding remarks}

The three case companies have extensive international activity. We do not know yet if they will achieve superior results compared to other companies in this industry with less international focus. Further studies need to investigate both the advantages and the disadvantages of an international orientation in the pre-commercial phases. When we evaluate the number of partnerships, the focus on technology development, the need for financial resources and the complexity of these processes combined with limited management capacity due to the size of the firms it is easy to conclude that managers in these companies face significant challenges. Even with these challenges, it is important to keep in mind the importance of new firms for job generation and economic development. Some firm in new industries emerges as winners with high growth levels and high return for investors. 


\section{References}

ANDERSON, C. R. (1984). Stage of the product life cycle, business strategy, and business performance, Academy of Management Journal, (5).

AUTIO, A. (2005). Creative tension: the significance of Ben Oviatt's and Patricia McDougall's article 'toward a theory of international new ventures'. Journal of International Business Studies 36(I).

AUTIO, E., H. J. Sapienza, et al. (2000). Effects of age at entry, knowledge intensity, and imitability on international growth, Academy of Management Journal, 43(5): 909-924.

BARNEY, J. B. P. (1997). Gaining and Sustaining Competitive Advantage.

BERGEK, A., S. Jacobsson, et al. (2008), Analyzing the functional dynamics of technological innovation systems: A scheme of analysis, Research Policy, 37(3): 407-429.

BLOMSTERMO, A., K. Eriksson, et al. (2004). The perceived usefulness of network experiential knowledge in the internationalizing firm, Journal of International Management, 10(3): 355-373.

BOYLE, R., C. Greenwood, et al. (2009). Global Trends in Sustainable Energy Investment 2008, United Nations Environment Programme.

BRUSH, C. G. (1995). International Entrepreneurship: The Effect of Firm Age on Motives for Internationalization, Routledge.

COHEN,W. M. and D. A. Levinthal (1990). Absorptive capacity: A new perspective on learning and innovation, Administrative Science Quarterly, 35(I): I28-152.

COLLIS, D.J. and C.A. Montgomery (1997). Corporate Strategy: Resources and The Scope of The Firm, McGraw-Hill.

COLLIS, D. J. and C.A. Montgomery (1999). Competing on Resources: Strategy in the 1990s. Knowledge and strategy. M. H. Zack, Butterworth-Heinemann: 25-40.

COOMBS, J. E. and D. L. Deeds (2000). International alliances as sources of capital: Evidence from the biotechnology industry, Journal of High Technology Management Research, II (2): 235.

COVIELLO, N. (1997). Network relationships and the internationalisation process of small software firms, Scandinavian International Business Review 6(4): 36I.
COVIELLO, N. and H. Munro (1997). Network relationships and the internationalisation process of small software firms, International Business Review, 6(4): 36I-386.

COVIELLO, N. E. (2006). The network dynamics of international new ventures, Journal of International Business Studies, 37(5): 7 I 3.

COVIELLO, N. E. and M.P. Cox (2007). The resource dynamics of international new venture networks, Journal of International Entrepreneurship, 4(2-3): I I3.

COVIELLO, N. E. and M.V. Jones (2004). Methodological issues in international entrepreneurship research, Journal of Business Venturing, 19(4): 485-508.

CROOK, T. R., D. J. Ketchen Jr., J. G. Combs, and S. Y. Todd (2008). Strategic Resources and Performance: a Meta-analysis. Strategic Management Journal 29 (I I): I I4 I-I I 54.

ENCAMATION, D. J. and L. T. Wells Jr. (I986). Competitive strategies in global industries: A view from host governments. Competition in global industries. M. E. Porter. Boston, Harvard Business School Press.

ETEMAD, H. (2004). International Entrepreneurship as a Dynamic Adaptive System:Towards a Grounded Theory. Journal of International Entrepreneurship 2(I/2): 5.

ETEMAD, H. (2004). Internationalization of Small and Medium-sized Enterprises: A Grounded Theoretical Framework and an Overview. Canadian Journal of Administrative Sciences $2|(I):|-2 \mid$.

FEDSPENDING (2009). www.fedspending.org (assessed 20.01.2009).

FOXON, T. J., R. Gross, et al. (2005). UK innovation systems for new and renewable energy technologies: drivers, barriers and systems failures. Energy Policy 33: 2123-2137.

GABRIELSSON, M. and V. H. M. Kirpalani (2004). Born Globals: How to Reach New Business Space Rapidly. International Business Review 13:555-57l.

GREENWOOD, C., A. Hohler, et al. (2008). Global Trends in Sustainable Energy Investment 2007, United Nations Environment Programme.

HOLMES, B., K. Nielsen, et al. (2007). Wave Energy Development \& Evaluation Protocol. 7th European Wave \& Tidal Energy Conference. Porto, Portugal. 
IEA (2006). Review and Analysis of Ocean Energy Systems Development and Supporting Policies, International Energy Agency.

IEA (2006). Review and Analysis of Ocean Energy Systems Development and Supporting Policies, International Energy Agency.

JONES, M.V. (200I). First steps in internationalisation-Concepts and evidence from a sample of small high-technology firms. Journal of International Management 7(3): |9|-210.

JONES, M.V. and N. E. Coviello (2005). Internationalisation: Conceptualising an Entrepreneurial Process of Behaviour in Time. Journal of International Business Studies 36(3): 284303.

KAZANJIAN, R. K. (1988). Relation of dominant problems to stages of growth in technology-based new ventures. Academy of Management Journal 3I(2): 257.

KORHONEN, H., R. Luostarinen, et al. (1996). Internationalization of SMEs: Inward--outward patterns and government policy. Management International Review 36(4): 315.

KUEMMERLE, W. (2002). Home base and knowledge management in international ventures. Journal of Business Venturing 17(2): 99-1 22.

LONDONSTOCKEXCHANGE (2004). AIM - The most successful growth market in the world. London.

LONDONSTOCKEXCHANGE (2009). "www.londonstockexchange.com, code OPT (assessed 20.01.2009)."

LØVDAL, N. S. and A. Aspelund (2010). International Entrepreneurship in the Offshore Renewable Energy Industry. Handbook of Research on Energy Entrepreneurship. R. Wustenhagen and R.Wuebker, Edward Elgar Publishing.

LUOSTARINEN, R. (1979). Internationalization of the firm. Helsinki School of Economics, Dissertation, Series A: 30, Helsinki School of Economics, Helsinki.

MALERBA, F. (2002). Sectoral systems of innovation and production. Research Policy 3I (2): 247.

MCDOUGALL, P. P. (1989). International versus domestic entrepreneurship: New venture strategic behavior and industry structure. Journal of Business Venturing 4(6): 387-400.

MEG (2004). Harnessing Scotland's Marine Energy Potential; Report for the Scottish Executive, Marine Energy Group.
MEI (2007). Decreto-Lei n.o 225/2007. M. D. E. E. D. INOVAÇÃO.

MOEN, $\varnothing$. (1999). The relationship between firm size, competitive advantages and export performance revisited. International Small Business Journal I8(I): 53 .

MOEN, $\varnothing$. (2002). The Born Globals - a new generation of small European exporters. International Marketing Review 19 (2): I56- 175.

OCEANPOWERTECHNOLOGIES (2008). Annual Report For The Year Ended April 30, 2008 (see www.oceanpowertechnologies.com)

OVIATT, B. M. and F. McDougall (1994). Toward a theory of international new ventures. Journal of international business studies 25(I): 45 .

PENROSE, E. T. (1959). The Theory of the Growth of the Firm, Oxford University Press.

PETERAF, M. A. (1997). The cornerstone of competitive advantages:A resource based view. Resources; Firms; and Strategies:A Reader in the Resource-Based Perspective. N.J. Foss, Oxford University Press.

PORTER, M. E. (1990). The Competitive Advantage of Nations, Free Press.

POUDER, R. and H. S. J. Caron (1996). Hot Spots and Blind Spots: Geographical Clusters of Firms and Innovation, The Academy of Management Review, 21 (4): I I 92- 1225.

PRASHANTHAM, S. (2008). New Venture Internationalization as Strategic Renewal, European Management Journal, 26(6): 378 .

RENNIE, M. W. (1993). Born Global, The McKinsey Quarterly, (4): 45-52.

RIALP, A., J. Rialp, et al. (2005). The Phenomenon of Early Internationalizing Firms: What do we know after a Decade (1993-2003) of Scientific Inquiry?, International Business Review, I4(2): I 47-I66.

ROSS, D. (1995). Power from the Waves, Oxford University Press, New York.

ROUSE, M.J. (1999). Rethinking research methods for the resource-based perspective: isolating sources of sustainable Competitive advantage. Strategic Management Journal 20(5): 487-494. 
SAPIENZA, H. J., E. Autio, et al. (2006). A Capabilities Perspective on the Effects of Early Internationalization on Firm Survival and Growth, The Academy of Management Review, $3|(4): 9| 4$.

SARASVATHY, S. D. (200I). Causation and Effectuation: Toward a Theoretical Shift from Economic Inevitability to Entrepreneurial Contingency, The Academy of Management Review, 26(2): 243.

SHARMA, D. D. and A. Blomstermo (2003). The Internationalization Process of Born Globals: a Network View, International Business Review, 12(6): 739-753.

STEGER, U. (2005), Sustainable Development and Innovation in the Energy Sector, Springer.

STERN, N. H. (2007). The Economics of Climate Change: the Stern Review. Cambridge, Cambridge University Press.

TAYLOR, G.W. (2006). AIM Admission Opens Doors to Investment Community, Infrastructure Journal Spring.

VAN DE VRANDE, V. and W. Vanhaverbeke (20I2). How Prior Corporate Venture Capital Investments Shape Technological Alliances:A Real Options Approach. Entrepreneurship Theory and Practice.

WELCH, L. S. and R. K. Luostarinen (1993). Inward-Outward Connections in Internationalization, Journal of international marketing, I (I): 44 .

WERNERFELT, B. (1984), A resource-based view of the firm. Strategic Management Journal 5: |7|-|80.

YIN, R. K. (2003). Case Study Research - Design and Methods, Sage Publications.

ZAHRA, S. A. (2005). A Theory of International New Ventures: a Decade of Research, Journal of International Business Studies, 36(I): 20.

ZAHRA, S.A. and G. George (2002). International Entrepreneurship: The Current Status of the Field and Future Research Agenda. Strategic Entrepreneurship: Creating an Integrated Mindset: 255-288.

ZAHRA, S.A., B. P. Matherne, et al. (2003). Technological Resource Leveraging and the Internationalisation of New Ventures, Journal of International Entrepreneurship, I(2): 163186. 